\title{
IFNL1 Gene
}

National Cancer Institute

\section{Source}

National Cancer Institute. IFNL1 Gene. NCI Thesaurus. Code C104350.

This gene plays a role in both the antiviral response and signaling. 